\title{
Inland waterways transport for city logistics: a review of experiences and the role of local public authorities
}

\author{
M. Janjevic \& A. B. Ndiaye \\ Université Libre de Bruxelles, Belgium
}

\begin{abstract}
Urban freight transport is increasingly difficult to organize and manage: the demographic expansion of cities, the environmental issues, new logistical trends, scarcity of space and the evolving consumer habits are just some of the challenges. In most cities, road transportation is essentially the only mode used for performing urban distribution of goods. Inland navigation is used solely for transport of bulk materials over long distances bulk material (e.g. construction material and agricultural products). However, experiences in several European cities have demonstrated that the use of inland waterways can be a viable alternative for smaller-scale freight transport in urban areas. This present article aims at reviewing current experiences in the field of inland navigation for city logistics. Through the analysis of several implementation cases in Europe, we demonstrate that inland navigation can be used for various segments of the urban freight transport, including transportation of palletized goods (e.g. construction and industrial material), transportation of containerized goods (e.g. for the supply of the supermarkets), deliveries to local shops and restaurants, deliveries of parcels, transport of waste and recycled material and service trips. Furthermore, the article analyses the conditions in which these transport schemes were developed, highlights their key success factors, and investigates the particular role of local public authorities in organizing and managing these innovative transport schemes.
\end{abstract}

Keywords: urban freight transport, city logistics, inland waterways, inland navigation, public authorities. 


\section{Introduction}

Urban freight transport is essential for the economy and the livability of the cities, but also a source of significant externalities [1]. In order to address the inefficiencies of urban transportation systems, city authorities have invested in a portfolio of solutions, but the focus has been often been limited to the mobility of passengers and not freight [2,3]. However, although urban freight transport represents about $10-15 \%$ of vehicles-km in urban areas, it is responsible for $19 \%$ of energy consumption of the road transportation, $25 \%$ of $\mathrm{CO} 2$ emissions, $30 \%$ of NOx emissions and $50 \%$ of particles [2]. Urban freight transport is also expected to grow both in terms of the transported volumes (due to demographic expansion of the cities) and in terms of the number of deliveries combined with the increase of the number of deliveries per person (due to some new logistical trends and the evolving consumer habits [4-6]). This makes urban freight transport increasingly difficult to organize and manage.

In most cities, urban freight transport is almost exclusively performed by road. Railways and waterways are seldom used for carrying goods in urban areas [7]. Several authors (e.g. [8,9]) acknowledge the potential of shifting a part of inter-urban flows towards the waterway network. In fact, inland waterways are the only land infrastructure with free capacity and are therefore not subject to congestion problems. Inland navigation is the most energy and carbon-efficient mode as a ship uses 1 to 2 times less fuel than a train and 3 to 5 times less fuel than a truck and can be economically competitive $[10,11]$. In Europe, inland navigation is already commonly used for the transportation of bulk materials over longer distances and consequently to supply port-cities in those products. In Brussels, the share of inland navigation in the city supply is $20 \%$ [12], and is essentially composed of construction materials (57\%) and petroleum products $(26 \%)$ [13]. In Paris area, the waterways also accommodate a lot of traffic, particularly building materials $(75 \%)$ and agricultural products $(9 \%)$, but they still remain significantly under-used [9].

Recent experiences in city logistics show that inland navigation can be competitive not only for bulk transportation over long distances but also for smaller-scale freight transport in dense urban areas.

Quite a few studies have reviewed intermodal opportunities for city logistics [14] and even fewer have focused on initiatives using the inland waterway network. Nemoto et al. [15] builds a general research framework for intermodal transport in the context of city logistics and provides few examples of implementation of city logistics solutions using waterborne transport. Dizain et al. [16] describes urban logistics solutions implemented in France and Japan using rail and waterway networks. Maes et al. [17] analyses several waterborne city distribution concepts, mostly in Netherlands and assesses their applicability to Flanders region. Quak [18] analyses 106 urban freight transport initiatives and addresses the issue of the intermodal transport for city logistics. A report by Inland Navigation Europe and European Federation of Inland Ports [19] also provides several examples of inland navigation used for the city distribution. 
This present article aims at reviewing current experiences in the field of inland navigation for urban freight transport. In the first section of the article, we will present several cases of implementation of city logistics schemes using inland navigation in Europe. In the second section of the article, we will highlight the key success factors relevant to these schemes and investigate the particular role of local public authorities in their implementation. We will conclude by assessing the overall potential of shifting urban freight flows towards the inland waterway network.

\section{Review of city logistics solutions using inland navigation}

Although the definition of the urban freight transport varies according to authors (for example: [20-23]) and can include or exclude elements such as shopping trips or through traffic, it is widely acknowledged that urban freight transport is composed out of several segments which differ according to the type of products, actors or characteristics of the deliveries, such as: transportation of construction material and industry, distribution to supermarkets, distribution to local shops, hotels and restaurants, service trips, courier and express services and waste and return logistics. The analysis of city logistics solutions in Europe has allowed us to identify specific solutions using inland navigation relevant to all segments of urban freight transport. Table 1 shows examples of urban freight transport initiatives involving inland navigation and identifies the relevant urban freight transport segment, the stakeholders (both private and public) involved in the initiative and the estimated environmental impact of the logistical solution. We will now briefly describe implementation details behind each of these logistical schemes.

The Beer Boat in Utrecht is one of the first modern urban logistics concepts using water [17]. Since 1996, the city uses the Beer Boat to supply drinks and food to more than 70 catering industries located along the canals of Utrecht [30]. The Beer Boat is owned by the municipality, which leases the boat to companies that provide the actual distribution services [30]. In 2010 the Beer Boat that operates on diesel was replaced by an electric, zero emission Beer Boat [30]. The electric beer boat has a length of 18.8 metres and a width of 4.2 metres, uses green energy and can be driven up to 8-9 hours on one charge [29] and can carry 18 tonnes of cargo (40-48 containers). Due to the success of the project, in 2012 the Municipality of Utrecht decided to expand the project and buy another electric boat that could carry greater volumes to transport - among other products - waste from the city centre [29]. The success of this implementation has led other Dutch cities like Amsterdam, Gouda and Woerden to consider using (electric) boats for freight transport in the inner city [30].

In Amsterdam, such a concept was already implemented by Mokum Maritiem who uses an electric boat, the City Supplier, to deliver goods in the inner city. Mokum Maritiem resulted from cooperation between five companies involved in respectively waste collection, the transportation of cargo and canal cruises within the inner city of Amsterdam [31]. This logistical concept has been used to 
Table 1: Review of city logistics solutions using inland navigation.

\begin{tabular}{|c|c|c|}
\hline Initiative & Stakeholders involved & $\begin{array}{l}\text { Estimated environmental } \\
\text { impact }\end{array}$ \\
\hline $\begin{array}{l}\text { Beer Boat (Utrecht): } \\
\text { deliveries to local } \\
\text { shops, hotels and } \\
\text { restaurants }\end{array}$ & $\begin{array}{l}\text { City of Utrecht (Department of Public } \\
\text { Works), Four breweries, One catering } \\
\text { industry wholesaler, } 65-70 \text { final } \\
\text { customers }\end{array}$ & $\begin{array}{l}\text { First diesel Beer Boat: } \\
\text { reduction of emissions: } \\
\text { particles }(74 \%), \text { CO2 }(27 \%) \text {, } \\
\text { NOx }(85 \%) \text {; Electric Beer } \\
\text { Boat: reduction of } 98 \%, 94 \% \\
\text { and } 100 \% \text { respectively }\end{array}$ \\
\hline $\begin{array}{l}\text { Mokum Maritiem } \\
\text { (Amsterdam): } \\
\text { deliveries to local } \\
\text { shops and waste } \\
\text { transport }\end{array}$ & $\begin{array}{l}\text { Icova (waste transportation), } \\
\text { Koninklijke Saan (transport operator) } \\
\text { and } 3 \text { tour boat companies (Rederij 't } \\
\text { Smidtj”e, Rederij de Nederlanden and } \\
\text { Canal Company) }\end{array}$ & Information not available \\
\hline $\begin{array}{l}\text { Vert Chez Vous, } \\
\text { Paris (France): } \\
\text { parcel deliveries }\end{array}$ & $\begin{array}{l}\text { Vert chez Vous (city logistics operator), } \\
\text { Port of Paris, Navigable Waterways of } \\
\text { France, Euroflots (river transport) }\end{array}$ & $\begin{array}{l}\text { Allows avoiding } 15 \text { heavy- } \\
\text { duty vehicles and } 207.9 \mathrm{~kg} \text { of } \\
\mathrm{CO} 2 \text { per day }(51,975 \mathrm{~kg} \text { per } \\
\text { year) with a goal of } 30 \\
\text { vehicles and } 10,3950 \mathrm{~kg} \text { of } \\
\mathrm{CO} 2 \text { in the near future }\end{array}$ \\
\hline $\begin{array}{l}\text { DHL floating } \\
\text { distribution centre, } \\
\text { Amsterdam: parcel } \\
\text { deliveries }\end{array}$ & $\begin{array}{l}\text { DHL (transport operator), City of } \\
\text { Amsterdam }\end{array}$ & $\begin{array}{l}\text { Allows avoiding } 10 \text { cars } \\
\text { every day (reduction of } \\
150,000 \text { car-kilometres and } \\
12,000 \text { litres of diesel per } \\
\text { year) }\end{array}$ \\
\hline $\begin{array}{l}\text { Franprix, Paris: } \\
\text { supermarket } \\
\text { deliveries }\end{array}$ & $\begin{array}{l}\text { Franprix (supermarket retailer), Norbert } \\
\text { Dentressangle (logistics service } \\
\text { provider), Navigable Waterways of } \\
\text { France, Port of Paris, Terminal de Seine } \\
\text { and Paris Terminal (dock work), SCAT } \\
\text { (river transport) }\end{array}$ & $\begin{array}{l}\text { At full volume, the will allow } \\
\text { avoiding } 450,000 \mathrm{~km} \text { made } \\
\text { by road every and } 37 \% \\
\text { reduction of CO } 2 \text { emissions } \\
\text { in the entire supply chain }\end{array}$ \\
\hline $\begin{array}{l}\text { Sainsbury's, } \\
\text { London: transport of } \\
\text { food to } \\
\text { supermarkets }\end{array}$ & $\begin{array}{l}\text { Sainsbury's (supermarket chain), Port of } \\
\text { London }\end{array}$ & $\begin{array}{l}\text { If extended to all stores in the } \\
\text { same area, the system could } \\
\text { avoid some } 350,000 \text { road km } \\
\text { every year }\end{array}$ \\
\hline $\begin{array}{l}\text { POINT-P, Paris: } \\
\text { transportation of } \\
\text { palletized } \\
\text { construction } \\
\text { material }\end{array}$ & $\begin{array}{l}\text { Point-P (construction material } \\
\text { distributor), Le Freedom (river } \\
\text { transport), Navigable Waterways of } \\
\text { France, Paris Port Authority }\end{array}$ & $\begin{array}{l}\text { Allows avoiding } 2000 \text { trucks } \\
\text { per year and } 220 \text { tonnes of } \\
\text { CO2 per year }\end{array}$ \\
\hline Velib (Paris) & JC Decaux, Mairie de Paris & Information not available \\
\hline $\begin{array}{l}\text { Lille: river } \\
\text { transportation of } \\
\text { domestic waste }\end{array}$ & Port of Lille, Lille urban community & Information not available \\
\hline $\begin{array}{l}\text { Paper recycling by } \\
\text { barge, Paris (France) }\end{array}$ & $\begin{array}{l}\text { SITA and Syctom for the transports, } \\
\text { UPM Kymmene, Paris Port Authority, } \\
\text { Rouen Port Authoriry, Navigable } \\
\text { Waterways of France, French } \\
\text { Environment and Energy Management } \\
\text { Agency }\end{array}$ & $\begin{array}{l}\text { Allows avoiding around } \\
4,500 \text { truck movements per } \\
\text { year, } 40 \% \text { decrease in the } \\
\text { fossil energy consumption } \\
\text { and } \mathrm{CO} 2 \text { emissions }\end{array}$ \\
\hline
\end{tabular}

Sources: [17, 19, 24-29]. 
transport a variety of products such as food and beverages for restaurants, supermarkets and various shops, building material, linens for hotels, hospitals and healthcare facilities, books, refrigerated products [17]. Mokum Mariteam has also established a cooperation with Binnenstadservice: goods are bundled at a urban consolidation centre at the outskirts of town from where they are transported by the City Supplier to the city centre $[17,32]$.

Still in Amsterdam, DHL developed a "Floating Distribution Centre" which is a specially reconstructed boat that floats through the canals of Amsterdam from where bicycle couriers perform the last leg of delivery [33]. Until 1997 the canals were only allowed to be used for passenger transport but for this initiative, this rule had been changed [33]. The boat and other facilities were financed by the DHL and the city of Amsterdam provided labour to develop the project [33] [24]. The new way of transporting goods which has been further extended since 1997 allows a fast, flexible and accurate service as it is independent from traffic jams and other traffic blocks [33].

In Paris, a French service provider Vert chez Vous has been operating from 2012 a multimodal delivery service using two alternative modes for the urban distribution of small parcels of less than $30 \mathrm{~kg}$ [25]: a "warehouse barge" called Vokoli circulates on the Seine River with a fleet of 18 electrically assisted delivery cargocycles on board [9]. Starting from the port of Tolbiac (13th arrondissement), the Vert chez Vous barge performs a round-trip and unloads the electric bikes on up to ten stopovers - from there, the bikes serve the recipients all over Paris business to business [25]. The main clients of this service are: Raja (office supplies), Wala (cosmetics), Sanofi Aventis (pharmaceuticals), Muji and, more recently, Okaidi, a brand of clothes for children [9]. The service delivers about 4,000 parcels every day [9].

Another Parisian example is the French supermarket Franprix, who uses river transport to deliver food products on a daily basis to 80 of its stores in the centre of Paris since 2012 [16]. The Regional Distribution Centre (warehouse) of Franprix is located in Chennevières-sur-Marne, about $20 \mathrm{~km}$ South-East of Paris [34]. On weekdays, from 05.00 to $11.30,450$ pallets of goods are prepared and then loaded onto 26 containers that are specifically designed for intermodal waterways transport [34]. Containers are transported by truck to an inland port for transfer to a barge for the $20 \mathrm{~km}$ journey along the Marne and Seine rivers to the heart of the French capital - thus avoiding chronic road traffic congestion into Paris $[35,36]$. Final deliveries are made by the transport company Norbert Dentressangle using regular diesel trucks [16]. Authorities made a financial participation in this project $[35,36]$.

A similar logistical solution was tested by Sainsbury's (a large supermarket chain in the UK) in February 2007 who tested delivering food to its London stores by river rather than road [19]. Once food is dispatched by Sainsbury's distribution centre in South East London, the day's delivery for the store would be shipped on the Thames by barge, rather than by road, arriving in close proximity to the west London store [19]. This trial tested the potential of the upper river for moving time-sensitive goods [19]. 
Still in Paris, a self-service bicycle scheme called "Vélib" is making use of the Seine to transport bicycles and mechanics swiftly from one stopping point to another, 12 in total, along the river [19]. The vessel, which has been in service since July 2007 is equipped with a mobile on-board crane capable of transhipping 5 bicycles [37]. The vessel is fully equipped for repairs and storage, and 4 mechanics work onboard and repair between 30 and 40 bikes a day [37].

The city of Lille (France) has been using a barge system for the transport of domestic waster since 1999 when the city had to close its incinerators for domestic waste which had previously processed up to 1,300 tonnes of waste a day [19]. The port of Lille organised a barge system with open top containers to send part of its domestic refuse to a landfill plant in the area [19]. Every day, between 30 and 40 containers were sent by barge [38]. Since September 2007, Lille's 2 most important valorisation plants are linked by barges, transporting a volume of approximately 220,000 tonnes per year [19].

In Paris, Syctom (Household waste treatment company) and the paper company UPM Kymmene operate a truly unique system which consists in shipping collected old newspapers and magazines for recycling to Grand-Couronne (Rouen) with a motorbarge equipped with an onboard crane, and sending back the newly manufactured paper rolls $(2.5 \mathrm{~m}$ wide) by ship to Paris where they are be used to print daily newspapers and magazines [19]. The operation started in 2005 with 17,000 tons of paper and reached 113,000 tonnes per year in 2008 [39].

Again in Paris, on the Seine, there is since 1987 a weekly distribution of 900 pallets of bags of various construction material (cement, concrete blocks, etc.) to Point $\mathrm{P}$ stores (distributor of construction material) which are often situated on the quayside [40]. This traffic uses a special self-unloading vessel "Madagascar" equipped with a crane [41].

The analysis of these implementation cases in Europe shows in fact inland navigation can be used for various segments of the urban freight transport, including transportation of palletized goods and containerized goods, deliveries to local shops and restaurants, deliveries of parcels, transport of waste and recycled material and service trips.

\section{Identification of key success factors and discussion on the role of local public authorities}

The analysis of case studies has led us to highlight some common success factors for the implementation of city logistics schemes using the inland navigation, both regarding the external environment in which they were implemented and those linked to the implementation setting. We will address them one by one.

Regarding the external environment conditions, the first element concerns the density of inland waterways. In fact, as noted by Quak [18], although this initiative type especially appeals to policy-makers' imaginations, since it shows concretely the change in transport and proves that polluting trucks are replaced, in most cities, water networks are usually not dense enough to deliver a 
considerable part of the urban freight volume [18]. In particular, small-scale urban freight solutions (such as deliveries of parcels or distribution to local shops and restaurants) will be greatly dependent on the density of inland waterways in the area.

The location of the receivers of freight along the waterway network will also be of major importance for the success of these initiatives. The waterborne logistical scheme implemented by POINT $\mathrm{P}$ in Paris is in fact only possible because of the location of their distribution agencies along the Seine, on the "quayside" [41]. Same consideration can be made regarding the position of Beer Boat customers in Utrecht or Mokum Mariteam in Amsterdam. However, Parisian examples "Vert chez Vous" and Franprix show that using road vehicles (tricycles and CNG trucks respectively), can increase the working radius of these solutions (deliveries to shops situated up to $4 \mathrm{~km}$ from the quay for Franprix experience) [34] and can therefore remedy the density and location problem to a certain extent.

The location of the shippers along the waterways or the presence and the location of platforms allowing transhipping and bundling goods before transferring them to water will also have a major impact on the possibility to introduce waterborne solutions for urban freight transport. One of the key success factors of Syctom experience resides in the location of the centre and a storage area on the waterfront in Gennevilliers [26]. Mokum Maritiem has signed a cooperation agreement with Binnenstadservice (urban consolidation centre) in order to facilitate bundling of goods before transferring them to water [17].

Compared to the road transport, inland navigation solutions for city logistics will be competitive only if there are significant accessibility problems in their service areas. This is particularly true for small-scale solutions. These accessibility problems can be linked to the physical environment in which one the urban freight distribution must be performed. In Utrecht, pubs and restaurants are located at a canal quay located lower than the road, making these premises difficult to access by truck, since a driver has to carry all beverages one level lower by stairs [18]. The water is at the same level as the premises, which makes waterborne distribution ideal [18]. In Amsterdam, the infrastructure of the inner city of Amsterdam is characterised by a lot of small streets and many obstacles in transportation by road [31]. Furthermore, these accessibility problems can be linked to the traffic density and congestion: in London Sainsbury experience, it was demonstrated that freight moves faster on the river than on central London's roads as there is no traffic build-up [19]. Finally, the low accessibility can be due by to the traffic and access restrictions, for freight vehicles: in Utrecht, the Beer Boat sails through the canals of Utrecht and has no restrictions on the maximum axle load, time windows, one-way streets, weight and length restrictions as the regular freight vehicles [17]; in Amsterdam, there are numerous policy constraints (time windows, environmental zones, etc.) which prevent the logistics industry from working optimally [17].

We can already conclude that the implementation of this type of initiatives is extremely relevant for urban centres with a sufficient density of inland 
waterways connecting a sufficient number of receivers and shippers and/or transhipment platforms enabling the intermodal transport chains and with serious accessibility problems for regular freight vehicles.

Among other enablers of waterborne urban freight distribution, we can mention the usage of special vessels and equipment and specific load units. In fact, for solutions such as Vert Chez Vous, Vélib, Beer Boat or Mokum Maritiem, the use of self-loading/unloading vessels with a loading crane and all equipment available on the ship facilitates the transhipment operations and reduces the impact of these solutions on the landscape. In Vert Chez Vous case, it allows a seamless transition between the boat and the bikes, therefore increasing the action radius of these solutions. The use of specific load units specifically designed for intercity transport was already highlighted by Nemoto et al. [15] as one of the enablers of intermodal city logistics. In fact, the Sytcom experience in Paris was only possible after the introduction of a new type of swap bodies (Intermodal Transport Units or UTI) enabling the transport of paper rolls since conventional shipping containers were not suitable [27].

Regarding the implementation details of the waterborne city logistics schemes, and the role of public authorities, we will first analyse the origin of the initiative. In fact, as stated by Anderson et al. [42], there are two main types of urban logistics measures depending on the stakeholders that are implementing them: changes implemented by governing bodies and company-driven changes. The review of experience shows that the majority of the initiatives were driven by the private sectors (e.g. DHL floating distribution centre, Franprix river logistics, etc.). Some initiatives such as Beer Boat in Utrecht are driven by the public sector, but the Mokum Mariteam initiative, which is very similar, is in fact driven by private stakeholders. We therefore cannot conclude that the origin of the initiative (private or public) is likely to influence the success of the initiative.

However, the inclusion of all relevant stakeholders (both private and public) seems to be a crucial element for the success of these solutions. As shown on Table 1, all of the analysed solutions are in fact Public-Private Partnerships where public authorities are represented through the municipal authorities, port and navigation authorities.

Their contribution often resides in some type of financial participation in the project. In fact, as noted by Diziain et al. [16], the total cost of urban freight waterway project (including transhipment) is often a challenge. Moreover, as noted by Maes et al. [17], for water-related concepts which are developed entrepreneurs, the cost per shipment is competitive with road transport only at sufficient volumes and the start-up phase is often difficult - the support of authorities is therefore often necessary. Regarding the considered initiatives, we can in fact observe that local public authorities have often brought financial contribution. In Utrecht Beer Boat experience, the purchase costs of the zero-emission boat was amounted to about $€ 800,000$, of which $€ 400,000$ was funded by local public authorities [17] and the remaining amount was financed from the operation of the first Beer Boot [17]. In Paris, the operator Vert Chez Vous received a subsidy from Voies Navigables de France for the ship crane and 
is due to receive additional support for the upgrade of the vessel [26, 35, 43]. The Mokum Mariteam initiative, although driven by the private sector and currently self-sustaining has also benefited from punctual grants from Doen Foundation, Secretary of State for Transport and Nord Holland Province [44].

Another important area of the intervention from public bodies resides in the provision of infrastructure for transhipment operations in the urban areas and in efficiently inserting dock and storage facilities in the urban landscape. In Franprix case, the river side facility La Bourdonnais has been restored by Ports of Paris in view of creating this logistic solution involving waterway transport [26]. Full integration of the logistics activity in the urban landscape was the primary focus of the refurbishment works at la Bourdonnais and the river bank remains open for other purposes as well [26].

\section{Conclusion}

The present article reviews experiences in the field of inland navigation for city distribution. Although inland navigation is typically used for transportation of bulk material, we have also demonstrated that some small-scale solutions exist. We have also highlighted their key success factors and highlighted the role of public authorities and bodies in implementing these initiatives.

Waterway urban freight transport was considered to be feasible only in specific circumstances, for a limited part of the total urban freight volume and only in cities with a very high density of waterway networks [18]. However, the analysis of several initiatives in European cities has led us to demonstrate that there is a significant potential for using city waterway networks for the distribution of goods in several urban freight transport segments, ranging from parcel deliveries to waste transportation, and that a usage of road vehicles for the last leg of transport allows implementing these solutions in cities with a lower waterway network density, such as Paris.

Environmental and social benefits of these innovative city logistics schemes have been demonstrated. The cost of these solutions has been an area of concern - however, even though the contribution of public authorities is often necessary for the initial investments, we have highlighted a number of self sustaining schemes on long term. Regardless their potential financial contribution, local public authorities and bodies and in particular port authorities have been a significant enabler of this type of schemes. Currently, we are aware of five other European cities including Brussels, Paris, Berlin, Budapest, Vienna and Pisa which, supported by their port authorities, commit themselves to use water for urban distribution and to take into account of the waterway when developing urban mobility plans [45]. We therefore believe that the usage of the waterway networks in urban transport of goods will be a recurring practice in the following years. 


\section{References}

[1] Janjevic, M., Ndiaye, A.B., Which lines of action for local authorities to decrease environmental impact of urban freight transport? 13th World Conference on Transport Research, Rio de Janeiro, 2013.

[2] Janjevic M., Lebeau P., Strategy for the implementation of sustainable logistic concepts for the Brussels Capital Region, Univesité Libre de Bruxelles/Vrije Universiteit Brussel, Innoviris, 2013.

[3] Muñuzuri, J., Larrañeta, J., Onieva, L., Cortés, P., Solutions applicable by local administrations for urban logistics improvement. Cities, 22(1), pp. 15-28, 2005.

[4] Zunder, T., Urban Freight: Myths, Good Practices, Best Practices, Working Paper, Newcastle University, UK, 2011.

[5] Janjevic, M., Ndiaye, A.B., Downscaling the consolidation of goods state of the art and transferability of micro-consolidation initiatives, European Transport $\mid$ Trasporti Europei, 54(1), 2013.

[6] Janjevic, M., Ndiaye, A.B., Development and application of a transferability framework for micro-consolidation schemes in urban freight transport, 8th International Conference on City Logistics, Bali, 2013.

[7] Taniguchi, E., Kawakatsu, S., Tsuji, H., New co-operative system using electric vans for urban freight transport. Urban Transport and the Environment for the 21st Century, VI, pp. 201-210, 2000.

[8] Carlén, V., Josefsson, A., Olsson, L., The potential role of urban waterways in sustainable urban freight transport - A case study of mass transport from the construction of Västlänken, Chalmers University of Technology, Göteborg, 2013.

[9] Diziain, D., Ripert, C., Dablanc, L., How can we Bring Logistics Back into Cities? The Case of Paris Metropolitan Area. Procedia-Social and Behavioral Sciences, 39, pp. 267-281. 2012.

[10] European Commission, An Integrated European Action Programme for Inland Waterway Transport, 2006.

[11] PLANCO Consulting GmbH, Bundesanstalt für Gewässerkunde, Economical and Ecological Comparison of Transport Modes: Road, Railways, Inland Waterways - Summary of Findings, 2007.

[12] Bruxelles Mobilité, IRIS 2 - Plan de Mobilité, 2010.

[13] Port Brussels, Rapport annuel 2012, 2013.

[14] Lindholm, M., Urban freight transport from a local authority perspective a literature review. European Transport Trasporti Europei, 54, 2013.

[15] Nemoto, T., Browne, M., Visser, J., Castrp, J., Intermodal transport and city logistics policies. Recent Advances in City Logistics. The 4th International Conference on City Logistics, 2006.

[16] Diziain, D., Taniguchi, E., Dablanc, L., Urban logistics by rail and waterways in France and Japan. Proceedings of 8th International Conference on City Logistics, 2013. 
[17] Maes, J., Sys, C., Thierry V., Vervoer te water: Linken met stedelijke distributie? Universiteit Antwerpen, 2012.

[18] Quak, H., Urban freight transport: the challenge of sustainability. City distribution and urban freight transport: multiple perspectives, Edward Elgar Publishing, Cheltenham, pp. 37-56, 2011.

[19] Inland Navigation Europe/ European Federation of Inland Ports, Urban Transport, 2008.

[20] Allen, J., Anderson, S., Browne, M., Jones, P., A framework for considering policies to encourage sustainable urban freight traffic and goods/service flows, Transport Studies Group, London, 2000.

[21] Ogden, K.W., Urban Goods Movement: A guide to Policy and Planning, Ashgate, Aldershot, 1992.

[22] Routhier, J.L., Segalou, E., Durand, S., Mesurer l'impact du transport de marchandises en ville: le modèle de simulation FRETURB (V.1), 2001.

[23] Dablanc, L., Goods transport in large European cities: Difficult to organize, difficult to modernize. Transportation Research Part A: Policy and Practice, 41, pp. 280-285, 2007.

[24] Eichwald, H., van der Ploeg, S., DHL's Floating Distribution Centre, 1999.

[25] Voies Navigables de France, Urban waterway logistics, 2013.

[26] Voies Navigables de France, Exemples de logistique fluviale urbaine, 2013.

[27] Avec UPM, les papiers préfèrent la Seine, http://www.vnf.fr/vnf/ img/cms/Tourisme_et_domainehidden/dossier_de_presse_200809191716. pdf, UPM, 2008.

[28] Mokum Mariteam - Initiatiefnemers, http://www.mokummariteam.nl/38Initiatiefnemers, Mokum Mariteam.

[29] Zero-Emission Beer Boat in Utrecht; BESTFACT project, http://www.bestfact.net/wp-content/uploads/2013/08/CL1_13_QuickInfo_ ZeroEmissionBoat-26July2013.pdf, 2013.

[30] Bertens, C., Urban Logistics Practices - Case Study of the City of Utrecht, TURBLOG Project Deliverable 3.2, 2011.

[31] Rivers of the World, Atlas on inland waterways transport, 2010.

[32] Dijkhuizen, B., Binnenstadservice van start in Amsterdam, 2011.

[33] Alternative ways for distributing goods in Amsterdam: boat \& bikes (The Netherlands), http://www.eltis.org/index.php?id=13\&study_id=1495, ELTIS, 2012.

[34] Supermarket stores deliveries using waterways in Paris; BESTFACT project, http://www.bestfact.net/wp-content/uploads/2013/08/CL1_7_ QuickInfo_Franprix-en-Seine-26July2013.pdf, 2013.

[35] Région Ile de France, Communiqué de presse: Avec la Région, le fret innove pour des livraisons sur Paris plus écologiques, 2012.

[36] Food Freight Deliveries by Barge in Paris. http://www.sustainablecities net.com/models/food-freight-deliveries-bybarge-in-paris/, Sustainable Cities, 2012.

[37] Inland Navigation Europe, Paris bikes repaired on Seine barge, 2010. 
[38] Origer, G., Callens, A., Depierre, D., Garrido, M., Lonnoy, A.S., Drapier, D., Duchateau, M., Rapport final DIPCITY, 2006.

[39] Avec UPM, les papiers préfèrent la Seine, http://www.drakkaronline.com/ article65044.html, 2008.

[40] Burg, D., Heulard, A., Martin, C., Dossier fluvial: Voies navigables de France accompagne les projets de livraison fluviale au coeur des villes, Le Journal de la Marine Marchande, 4852, 2012.

[41] France Nature Environnement / Voies Navigables de France, Agir pour la logistique urbaine fluviale, 2013.

[42] Anderson, S., Allen, J., Browne, M., Urban logistics - how can it meet policy makers' sustainability objectives ? Journal of Transport Geography, 13(1), pp. 71-81, 2005.

[43] Maierbrugger, G., Floating warehouse and electric bikes form multimodal delivery service in Paris, http://www.naiades.info/platina/page. php?id=103\&path=102\&article=1840, PLATINA, 2012.

[44] Mokum Mariteam - Subsidieverstrekkers, http://www.mokummariteam.nl /57-Subsidieverstrekkers, Mokum Mariteam.

[45] The role of inland ports in urban logistics: back to basics, GreenPort, 2013. 